UDC 621.039.51

V. Gulik, $\mathrm{PhD}$,

V. Galchenko, $\mathrm{PhD}$,

I. Shlapak,

D. Budik

PJSC “SRPA “Impulse”, 2 Pl. Pobedy, Lugansk region, Severodonetsk, Ukraine, 93405 e-mail: volodymyr_gulik@ukr.net

\title{
DEVELOPMENT OF A THREE-DIMENSIONAL MODEL OF THE VVER-1000 REACTOR USING SERPENT MONTE CARLO CODE FOR NEUTRON-PHYSICAL MODELING
}

В.І. Гулік, В.В. Гальченко, І.І. Шлапак, Д.В. Будік. Розробка тривимірної моделі реактора ВВЕР-1000 за допомогою Монте-Карло коду SERPENT для нейтронно-фізичного моделювання. Дослідження реакторів ВВЕР $є$ важливою задачею для вітчизняної атомної енергетики. Для цього використовуються різні детерміністичні та стохастичні коди. Із значним прогресом в розвитку комп'ютерних систем з'явилась можливість активного використання стохастичних кодів (заснованих на методі МонтеКарло) для моделювання складних реакторних систем. В даній роботі представлено дослідження по застосуванню Монте-Карло коду для розрахунку всієї активної зони реактора ВВЕР-1000. Такі розрахунки дадуть можливість готувати так зване «інформаційне забезпечення» для моніторингового детерміністичного коду СВРК 3 високою точністю. В інформаційне забезпечення входять групові константи, коефіцієнти для розрахунку модельних токів, альбедні граничні умови для радіального та аксіальних відбивачів. В статті представлено використання нового Монте-Карло код Serpent для тривимірного моделювання активної зони реактора ВВЕР-1000. Застосування Монте-Карло кодів дозволяє аналізувати властивості широкий спектр нейтроннофізичних та теплогідравлічних характеристик активної зони в будь-якій точці ядерного реактора. В роботі були розроблені моделі активних зон для першого завантаження РАЕС4 та 28-го завантаження ЮУАЕС3. При цьому були підготовлені моделі ТВ3 різних виробників. При розробці моделі активної зони, значна увага була приділена детальному моделюванню верхнього, нижнього та бічного відбивачів. Валадаційні розрахунки Монте-Карло коду Serpent для реактора типу ВBEР-1000 були виконані на основі першого завантаження РАЕС4. Для 28-го завантаження ЮУАЕС3 були отримані альбедні граничні умови для радіального та аксіальних відбивачів. Підготовлені моделі активних зон реактора ВВЕР-1000 будуть використані для розрахунку «інформаційного забезпечення» для нового українського моніторингового детерміністичного коду СВРК - ImCore, що розробляється в ПАО «СНВО «Імпульс». Використання комп’ютерного коду заснованого на методі Монте-Карло дасть можливість підвищити точність «інформаційного забезпечення», і як наслідок, підвищити точність всього розрахунку ядерного реактора в СВРК.

Ключові слова: ядерний реактор, ВВЕР-1000, розрахунок ядерного реактора, Монте-Карло метод, моделювання активної зони

V. Gulik, V. Galchenko, I. Shlapak, D. Budik. Development of a three-dimensional model of the VVER-1000 reactor using SERPENT Monte Carlo code for neutron-physical modeling. The VVER reactor investigation is an important goal for Ukrainian nuclear energy. Different deterministic and stochastic codes are using for this purpose. With taking into account the fast development of computer systems, there is a possibility for active using stochastic codes (based on Monte-Carlo method) for simulation of complicated reactor systems. The investigation for implementation of Monte-Carlo code to calculate whole reactor VVER-1000 core was presented in this article. Such type of calculations would be a base for preparation of "information support data" with high accuracy deterministic code for in core monitoring system. The "information support data" includes group constants, coefficients for calculations of model currents, albedo boundary conditions for radial and axial reflectors. The paper presents the use of the new Monte-Carlo Serpent code for the three-dimensional modelling of the VVER-1000 reactor core. The use of Monte-Carlo codes offers an opportunity to analyze the properties of a wide range of the neutron-physical and thermal-hydraulic characteristics at any reactor point. In the work, core models were developed for the Rivne NPP4 first loading and the South-Ukraine NPP3 28th loading. At the same time, assembly models of various manufacturers were prepared. During the core model developing, considerable attention was paid to the upper, lower and side reflectors for detailed modelling. The Monte-Carlo Serpent code validation calculations for the VVER-1000 reactor were performed based on the Rivne NPP4 first loading. The albedo boundary conditions for radial and axial reflectors were obtained for the South-Ukraine NPP3 28th loading. The prepared VVER-1000 reactor core models will use for "information support data" calculations for new Ukrainian In-core monitoring system deterministic code - ImCore, which is under development at PJSC "SRPA “Impulse". Using computer code based on Monte-Carlo method will provide an opportunity for increasing accuracy of "information support data" and as a consequence, increase the accuracy for VVER-1000 reactor calculations in In-core monitoring system.

Keywords: nuclear reactor, VVER-1000, calculation of nuclear reactor, Monte Carlo method, core modeling

\section{Introduction}

Further development of nuclear power is impossible without the introduction of new computer codes, which are based on more accurate methods of calculating nuclear reactors. The use of such codes will ensure the reliable and safe operation of the NPP [1]. When operating a nuclear reactor, it is 
very important to understand the change in the characteristics of the core during the fuel campaign. Such characteristics may include the distribution of energy release in the core, the distribution of neutron flux density in the reactor, the temperature fields, the change in isotope composition, and others. All these characteristics are very important for the assessment of safe operation of the NPP. A threedimensional calculation of the nuclear reactor core, including simulations of neutron transfer, heat transfer, and isotope composition change, will allow the determination of the above characteristics of nuclear fuel anywhere in the core.

\section{Analysis of recent research and publications}

There are currently quite a few computer codes used for two- and three-dimensional calculations of the core [2, 3]. Such codes may use different approaches and methods to simulate neutron transfer in a nuclear reactor. In addition, different libraries of estimated nuclear data may be used for modeling. As a result, the simulation results of different codes should be compared with the operational data and the simulation results of other codes. Such comparative calculations in foreign literature are called benchmarking by modeling and cross-verification [4].

With the increase in the computing power of modern computers, reactor calculations are receiving increasing attention to the possibility of using computer codes based on stochastic methods, such as the Monte Carlo method [5]. The reactor codes, based on the Monte Carlo method, make it possible to work with different materials and isotopes, with complex geometry, and to determine different neutron-physical characteristics.

\section{The goal of the work}

The purpose of this work is to investigate the use of the new Monte Carlo Serpent code for the three-dimensional calculation of the VVER-1000 reactor core [6]. Features of modeling of geometry of fuel assemblies, core and fence in the Serpent code are considered. The first simulation results in the developed three-dimensional model of the core are presented.

\section{The main material}

Monte Carlo code Serpent. The Serpent Monte Carlo code was developed in 2004 by the VTT Technical Research Center (Finland) and has quickly gained the commitment of many scientists around the world at the expense of convenience, precision of calculations and a wide range of tasks it is capable of solving [6]. At the moment, the Serpent code is actively used to investigate reactors on both fast and thermal neutrons [7, 8]. The first version is available for free for scientific purposes and is distributed through NEA Data Base. Today, a second version of the Serpent code is being developed that has more functionality and some improvements to methods of calculating individual characteristics of a nuclear reactor.

The Serpent code is primarily used for the preparation of small-group homogeneous macroscopic characteristics for deterministic codes that solve the problem of calculating the entire core of a nuclear reactor. Serpent has a burnout module that allows you to track changes in isotope composition over time. Recently, the Serpent code has been used to calculate three-dimensional nuclear reactors, to obtain pin factors and albedo coefficients for deterministic codes.In addition, the Serpent code is able to calculate tasks with an external neutron source and photon transfer [9]. The only major drawback of the Serpent code is the lack of a heat-hydraulic module that would allow temperature feedback to be taken into account when calculating burnout across the entire core area.

Model of the VVER-1000 reactor. Within the framework of the presented article, threedimensional models of active zones were developed for the first fuel loading of Rivne NPP-4 and the 28th fuel loading of SUNPP-3.

As the Serpent code has a wide range of tools for using different types of geometry, different inputs (cards) were used to design the hexagonal geometry of the fuel assembly and the core, and the fence and top and bottom reflectors were designed in as much detail as possible. The Serpent code makes it possible to compose complex geometry from separate pre-formed parts of geometry (similarly to object-oriented programming). For example, fuel elements, uranium-gadolinium fuel rods, central tubes, instrument channels, reactor control and protection systems (RCPS) are formed by so-called pins. Formed pins are used to form fuel assemblies of different types, and from formed fuel assemblies we can collect the entire core. For example, for the first load of RivneNPP-4, four types of fuel assemblies were modeled: 16FL, 30FL, 42FLB, 44FLB. Fig. 1 shows the 30FL fuel assembly, and Fig. 2 presents the 30FL fuel assembly with lowered RCPS of group 10. 


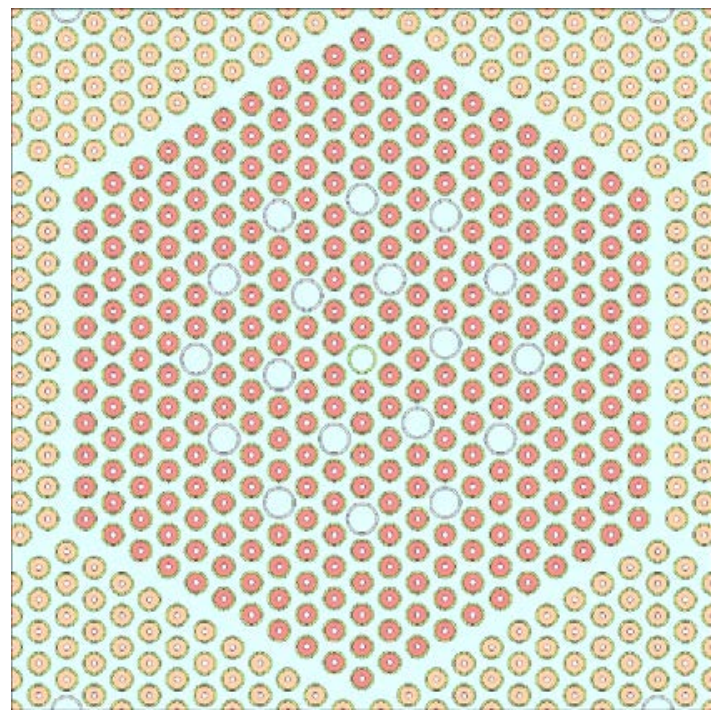

Fig. 1. Serpent Vizualization of fuel element $30 \mathrm{FL}$

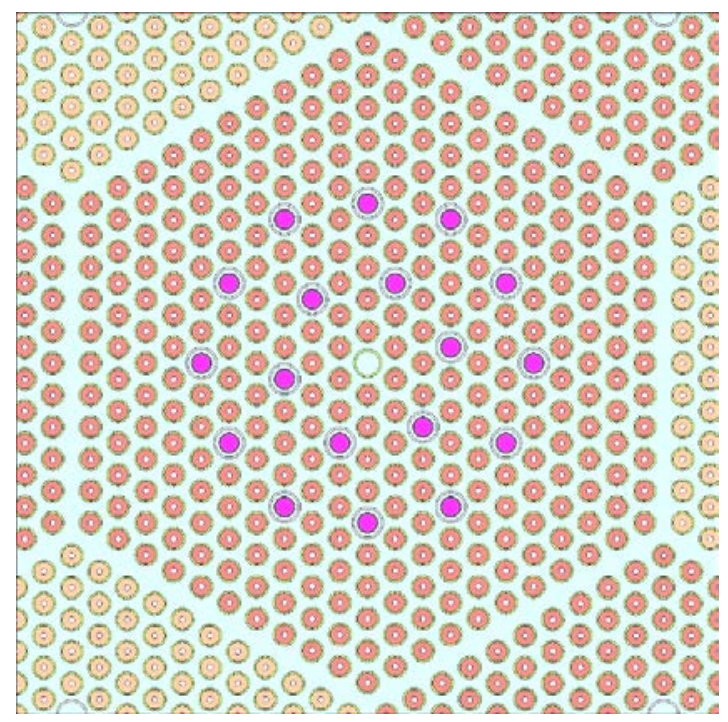

Fig. 2. Serpent Vizualization of fuel element $30 F L$ with RCPS

The Serpent code has the ability to construct the geometry of fuel assembly with the upper and lower reflectors using the so-called "vertical stack". The lower reflector has a height of $23.1 \mathrm{~cm}$ from the lower surface of the fuel. The reflector is divided into six different layers and covers the ends of the fuel elements, the lower grate, part of the bottom nozzle of the fuel assembly and part of the support cylinder. The top reflector has a height of $29.4 \mathrm{~cm}$ from the upper surface of the fuel to the bottom nozzle of the fuel assembly. The reflector is divided into five different layers and covers the ends of the fuel elements and the two upper spacer grids. 13 spacer grids that fit into the fuel part evenly smeared on the surfaces of the fuel elements, central tube and guide channels. Fig. 3 shows a horizontal section of the first core loading Rivne NPP-4, and Fig. 4 shows a vertical section of the first core loading Rivne NPP-4. The core zone model was developed in such a way that it could be used to calculate the boundary conditions for the ImCore deterministic code, which is being developed by PJSC JSC "Impulse" for the needs of the Ukrainian NPP incore monitoring systems.

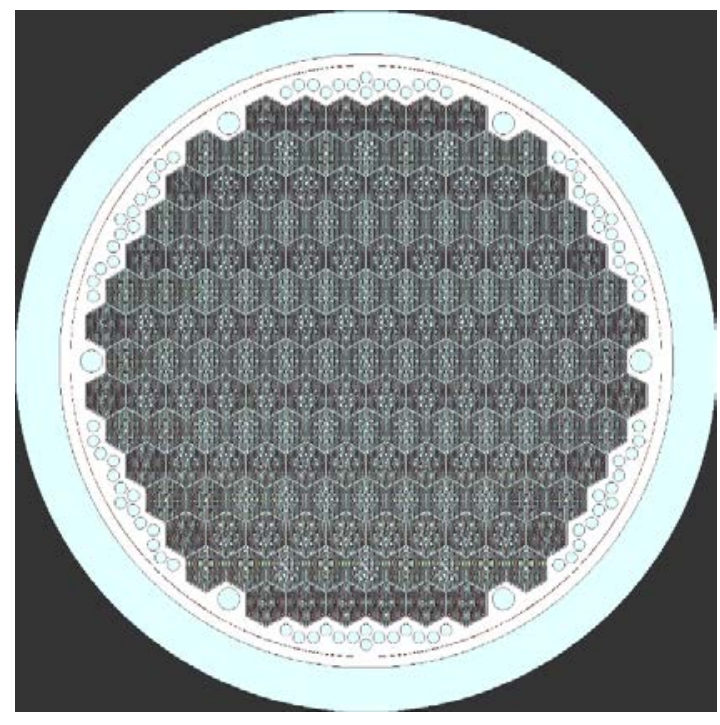

Fig. 3. Serpent visualization of the horizontal section of the core

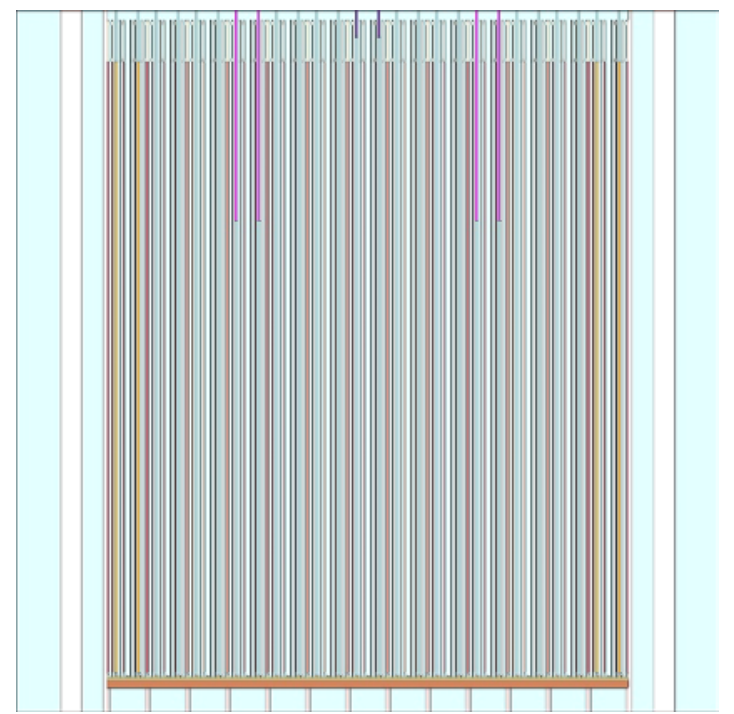

Fig. 4. Serpent visualization of the vertical section of the core 


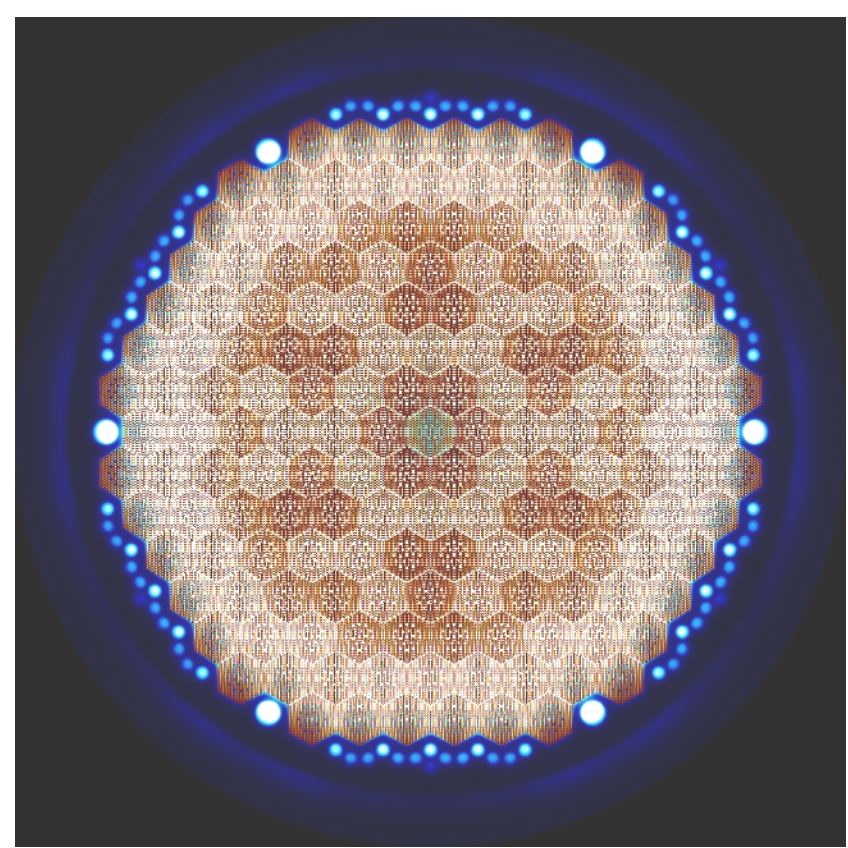

Fig. 5. Serpent mesh visualization of the horizontal section of the core

The boundary conditions are planned to be calculated in two variants:

1) Coefficients of the albedo (the ratio of neutron currents to the boundary of the active zone - reflector);

2) group constants for two rows of hexagonal prisms (with a turnkey size similar to a fuel assembly) surrounding the core and including the reactor wall.

\section{Results}

The modelling of the core zone in the Serpent code for Rivne NPP-4 for the first loading was performed in order to validate the Serpent code for the calculations of the core zones of the VVER-1000 reactors. This work is done in collaboration with HelmholtzZentrum Dresden-Rossendorfin (Germany), which specializes in reactor calculations for thermal and fast reactors, and the VTT Technical Research Center of Finland Ltd (Finland), developers of Serpent code. To date, the critical state of the core has been calculated for the first load of Rivne NPP-4 for the MKU. The modelling was performed using the "set pop 1000000100020 " option, where "1000000" is the number of neutrons per cycle, " 1000 " is the number of active cycles running, and " 20 " is the number of inactive cycles running. The latest version of the Serpent 2.1.30 code was used for the Serpent calculation. At the same time, a computing server with the following parameters was used to perform the simulation: Intel (R) Core (TM) i5-6600K CPU @ 3.50GHz processor and 32 GB RAM. As a result, an effective reproduction coefficient of 1.00162 was obtained with a statistical error of 0.00002 . The obtained modelling result suggests that the developed model of the VVER-1000 reactor core is suitable for neutron-physical calculations. Fig. 5 shows the so-called mesh rendering of the Serpent code for Rivne NPP-4 first loading, where warm tones (red-yellow) reflect "fission reaction density" and cold tones (blue and white) reflect "scattering reaction density".

The modelling of the core zone in the Serpent code for the 28th loading of SUNPP3 was performed for the purpose of the albedo coefficients used to determine the boundary conditions in the ImCore deterministic code, which is being developed by PJSC JSC "Impulse" for the needs of the Ukrainian NPP in-core monitoring systems. A model for Rivne NPP-4 was used to develop the model of the SUNPP-3 core. Westinghouse production facilities were used for the 28th loading of SUNPP-3. As a result of Serpent simulation, albedo coefficients can be obtained for each of the 90 lateral faces of the core, albedo coefficients for different types of symmetry, and albedo coefficients for the upper and lower reflectors both for the entire core and for each of the 163 fuel assemblies. Table presents the coefficients of albedo for the 28th loading of SUNPP-3 in the case of 90 degree symmetry (for the fast and thermal groups).

The obtained data allow us to set the boundary conditions for the ImCore deterministic code with high accuracy, which will allow to increase the accuracy of the calculation of the basic neutronphysical characteristics in the in-core monitoring system. 
Albedo coefficients for 90 degree symmetry in the case of two energy groups.

\begin{tabular}{c|c|c|c|c|c}
\hline \multirow{2}{*}{ Face number } & \multicolumn{2}{|c|}{ The coefficient of albedo } & \multirow{2}{*}{ Face number } & \multicolumn{2}{c}{ The coefficient of albedo } \\
\cline { 2 - 3 } & Fast group & Thermal group & & Fast group & Thermal group \\
\hline 1 & 0.632961 & 0.750208 & 13 & 0.644606 & 0.742458 \\
\hline 2 & 0.630331 & 0.746013 & 14 & 0.628376 & 0.750713 \\
\hline 3 & 0.643511 & 0.753326 & 15 & 0.634282 & 0.748426 \\
\hline 4 & 0.618045 & 0.746602 & 16 & 0.634039 & 0.747221 \\
\hline 5 & 0.695624 & 0.729589 & 17 & 0.631338 & 0.740564 \\
\hline 6 & 0.652509 & 0.662 & 18 & 0.643687 & 0.741676 \\
\hline 7 & 0.703635 & 0.762732 & 19 & 0.619768 & 0.74711 \\
\hline 8 & 0.587088 & 0.873451 & 20 & 0.694835 & 0.725301 \\
\hline 9 & 0.701729 & 0.766254 & 21 & 0.651275 & 0.650585 \\
\hline 10 & 0.65192 & 0.656855 & 22 & 0.701557 & 0.768628 \\
\hline 11 & 0.696597 & 0.720592 & 23 & 0.587656 & 0.86666 \\
\hline 12 & 0.618912 & 0.743077 & - & & - \\
\hline
\end{tabular}

\section{Conclusions}

The new Monte Carlo Serpent code has been used for three-dimensional modeling of the VVER-1000 reactor core. Within the framework of the presented work, core zone models were developed for Rivne NPP-4 first loading and SUNPP-3 28th loading. The Monte Carlo validation calculations of the Serpent code for the VVER-1000 reactor were performed on the basis of the first Rivne NPP-4 loading. For the 28th loading of SUNPP-3, albedo boundary conditions for radial and axial reflectors were obtained.

\section{Література}

1. Modeling and control of nuclear reactor cores for electricity generation: A review of advanced technologies / Li G., Wang X., Liang B., Li X., et al. Renewable and Sustainable Energy Reviews. 2016. Vol. 60. P. 116-128.

2. The reactor dynamics code DYN3D - models, validation and applications / Rohde U., Kliem S., Grundmann U., et al. Progress in Nuclear Energy. 2016. Vol. 89. P. 170-190.

3. Current status of the reactor physics code WIMS and recent developments / Lindley B.A., Hosking J.G., Smith P.J., et al. Annals of Nuclear Energy. 2017. Vol. 102. P. 148-157.

4. Galchenko V.V., Gulik V.I., Shlapak I.I. Using of the Serpent code based on the Monte-Carlo method for calculation of the VVER-1000 fuel assembly characteristics. Nuclear Physics and Atomic Energy. 2016. Vol. 17(3). P. 250-258.

5. Leppänen J., Pusa M., Fridman E. Overview of methodology for spatial homogenization in the Serpent 2 Monte Carlo code. Annals of Nuclear Energy. 2016. Vol. 96. P. 126-136.

6. The Serpent Monte Carlo code: Status, development and applications in 2013 / Leppänen J., Pusa M., Viitanen T., et al. Annals of Nuclear Energy. 2015. Vol. 82. P. 142-150.

7. Velocity Characteristic and Stability of Wave Solutions for a CANDLE Reactor with Thermal Feedback / Khotyayintsev V.M., Aksonov A.V., Khotyayintseva O.M., et al. Annals of Nuclear Energy. 2015. Vol. 85. P. 337-345.

8. Galchenko V.V., Shlapak I.I., Gulik V.I. The computational benchmark for fuel assembly of VVER1000 with using Monte Carlo Serpent code. Nuclear Technology \& Radiation Protection. 2018. Vol. 33(1). P. 24-30.

9. Radiation shielding properties of a novel cement-basalt mixture for nuclear energy applications / Ipbüker C., Nulk H., Gulik V., et al. Nuclear Engineering and Design. 2015. Vol. 284. P. $27-37$.

\section{References}

1. Li, G., Wang, X., Liang, B., \& Li, X., et al. (2016). Modeling and control of nuclear reactor cores for electricity generation: A review of advanced technologies. Renewable and Sustainable Energy Reviews, 60, 116-128.

2. Rohde, U., Kliem, S., \& Grundmann, U., et al. (2016). The reactor dynamics code DYN3D - models, validation and applications. Progress in Nuclear Energy, 89, 170-190. 
3. Lindley, B.A., Hosking, J.G., \& Smith, P.J., et al. (2017). Current status of the reactor physics code WIMS and recent developments. Annals of Nuclear Energy, 102, 148-157.

4. Galchenko, V.V., Gulik, V.I., \& Shlapak, I.I. (2016). Using of the Serpent code based on the MonteCarlo method for calculation of the VVER-1000 fuel assembly characteristics. Nuclear Physics and Atomic Energy, 17(3), 250-258.

5. Leppänen, J., Pusa, M., \& Fridman, E. (2016). Overview of methodology for spatial homogenization in the Serpent 2 Monte Carlo code. Annals of Nuclear Energy, 96, 126-136.

6. Leppänen, J., Pusa, M., \& Viitanen, T., et al. (2015). The Serpent Monte Carlo code: Status, development and applications in 2013. Annals of Nuclear Energy, 82, 142-150.

7. Khotyayintsev, V.M., Aksonov, A.V., \& Khotyayintseva, O.M., et al. (2015). Velocity Characteristic and Stability of Wave Solutions for a CANDLE Reactor with Thermal Feedback. Annals of Nuclear Energy, 85, 337-345.

8. Galchenko, V.V., Shlapak, I.I., \& Gulik, V.I. (2018). The computational benchmark for fuel assembly of VVER-1000 with using Monte Carlo Serpent code. Nuclear Technology \& Radiation Protection, 33(1), 24-30.

9. Ipbüker, C., Nulk, H., \& Gulik, V., et al. (2015). Radiation shielding properties of a novel cement-basalt mixture for nuclear energy applications. Nuclear Engineering and Design, 284, 27-37.

Гулік Володимир Іванович; Gulik Volodymyr, ORCID: https://orcid.org/0000-0002-3790-8392

Гальченко Віталій Володимирович; Galchenko Vitaliy

Шлапак Ігор Ігоревич; Shlapak Ihor

Будік Дмитро Володимирович; Budik Dmytro

Received November 14, 2019

Accepted December 27, 2019 